\title{
PENGGUNAAN MEDIA KADO ILMU DALAM MENINGKATKAN KEMAMPUAN MENULIS CERPEN PADA PESERTA DIDIK
}

\author{
Maria Weleng, Robertus Adi Soerjono Owon, Bernadus Bura \\ Pendidikan Bahasa dan Sastra Indonesia,Fakultas Ilmu sosial dan Humaniora, IKIP \\ Muhammadiyah Maumere, Maumere, Indonesia \\ mariaweleng15@gmail.com
}

\begin{abstract}
ABSTRAK: Penelitian ini bertujuan untuk mengangkat masalah mengenai penggunaan media kado ilmu dalam meningkatkan kemampuan menulis cerpen pada peserta didik. Penelitian ini merupakan salah satu jenis penelitian tindakan Kelas (PTK). Penelitian ini menggunakan metode deskriptif kualitataif yaitu pengumpulan data berupa data yang ditemukan pada saat melakukan penelitian dengan menggunakan media kadoilmu pada pesertadidik. Teknik yang dipakai dalam penelitian ini yaitu teknik non tes berupa observasi (pengamatan) terhadap peserta didik dan pendidik, dan teknik tes berupa hasil pekerjaan peserta didik yang di lakukan untuk mengetahui presentase ketuntasan hasilbelajar peserta didik. Teknik analisis data yaitu data hasil pekerjaan peserta didik yang dianalisis dengan cara membaca, memeriksa, dan menilai. Sehingga berdasarkan hasil penelitian tersebut disimpulkan bahwa pembelajaran dengan menggunakan media kado ilmu dapat meningkatkan kemampuan peserta didik dalam menuli scerpen, yakni dengan adanya ketuntasan belajar peserta didik pada siklus 1 yang tuntas 8 orang atau 28,57\%, yang tidak tuntas 20 orang atau $71,43 \%$ sedangkan pada siklus II jumlahpeserta didik yang tuntasmeningkat menjadi 27 orang atau $96,42 \%$, dengan 1 orang atau 4,00\% yang menunjukan tidak tuntas.
\end{abstract}

KATA KUNCI: Media Kadoilmu,Cerpen,Pesertadidik.

THE USE OF SCIENTIFIC MEDIA MEDIA IN IMPROVING THE WRITING ABILITY OF STUDENTS IN EDUCATION

\begin{abstract}
This study aims to raise the issue of the use of science gift media in improving short story writing skills in students. This research is one type of Classroom Action Research (CAR). This research uses descriptive qualitative method that is data collection in the form of data found at the time of conducting research using gift items on students. The techniques used in this study are non-test techniques in the form of observations (observers) of students and educators, and test techniques in the form of student work done to determine the percentage of completeness of student learning outcomes. Data analysis technique is the data of students' work which is analyzed by reading, checking, and assessing. So based on the results of the study it was concluded that learning by using science gift media can improve the ability of students in writing scerpenes, namely by completing the learning of students in cycle 1 which is complete 8 people or $28.57 \%$, which is not completed 20 people or $71,43 \%$ while in the second cycle the number of students who completed completed increased to 27 people or $96.42 \%$, with 1 person or $4.00 \%$ who showed incomplete.

KEYWORDS: Kadoilmu Media, Short Stories, Islamic Education Participants

\begin{tabular}{lccc}
\hline Diterima: & Direvisi: & Disetujui: & Dipublikasi: \\
2020-07-03 & 2021-01-14 & $2021-03-20$ & 2021-03-28 \\
Pustaka : Weleng, M., Owon, R., \& Bura, B. (2021). PENGGUNAAN MEDIA KADO ILMU DALAM \\
MENINGKATKAN KEMAMPUAN MENULIS CERPEN PADAPESERTA DIDIK. Fon : \\
Jurnal Pendidikan Bahasa dan Sastra Indonesia, 17(1), 25-33. \\
doi:https://doi.org/10.25134/fjpbsi.v17i1.3011. \\
\hline
\end{tabular}
\end{abstract}

\section{PENDAHULUAN}

Pada dasarnya pembelajaran bahasa Indonesia merupakan cara untuk meningkatkan kemampuan peserta didik dalam belajar berkomunikasi, baik secara lisan maupun tertulis, terutama dalam hal menulis cerita pendek. Cerita pendek merupakan salah satu bentuk karya sastra yang harus disajikan dengan efektif sehingga karya sastra tersebut dapat 
bermanfaat bagi pembaca dalam meningkatkan kemampuan berbahasa (Ahsin, 2016). Dengan kata lain, peserta didik yang tidak menguasai bahasa akan sulit berkomunikasi dengan baik dan benar yang akan mengakibatkan konsekuensi penggunaan bahasa menjadi kurang optimal. Ada empat macam keterampilan berbahasa yang diajarkan di sekolah seperti keterampilan mendengar, membaca, berbicara serta menulis, dari keempat keterampilan tersebut haruslah terjalin sedemikian rupa sehingga dapat mengahsilakan sebuah tulisan yang runtun dan efektif yang secara tepat sesuai dengan situasi dan kodisi pemakainnya terutama pada sebuah karangan cerita pendek (Suryadi, 2018, hlm. 232).

Menurut (Kette dkk, 2016, hlm. 698) menulis merupakan cara mengungkapkan ide atau gagasan dalam pikiran dan rasa melalui bahasa sebagai salah satu bentuk ekspresi. Dengan kata lain, menulis adalah bagian dari proses mengungkapkan gagasan dalam bentuk bahasa secara tertulis. Keterampilan menulis tidak akan datang secara otomatis, melainkan harus melalui latihan atau praktik yang banyak dan teratur karena keterampilan menulis memiliki tingkat kesulitan lebih besar dibandingkan dengan yang lainnya (Ulfah dan Soenarto, 2017, hlm. 22). Lebih lanjut Santoso dkk (2010, hlm. 6.15-6.17), menegaskan bahwa pembelajaran menulis dapat dilaksanakan dengan (1) langsung menulis teori belakangan,(2) menulis mulai dari titik awal yang pasti, mulai darimanapun boleh, (3) menulis dengan mengerahkan seluruh pengetahuan dengan belajar sambil bercanda, (4) menanamkan kebahasaan dan kecintaan menulis dengan pembelajaran menulis nonlinear.Oleh karena itu menulis dapat dilakukan kapan dan dimana saja, sesuai dengan apa yang dialami dalam kehidupan sehari- hari.
Menulis dengan latihan-latihan tersebut termasuk teknik menuangkan berbagai ide yang ada dalam pikiran seseorang (Sehandi, 2016, hlm. 53). Hal ini tidak mudah dilakukan oleh banyak orang untuk itu, keterampilan menulis harus diajarkan secara sistematis oleh pendidik agar dapat mencapai tujuan yang diharapkan yakni, pendidik dituntut agar memiliki pengetahuan dan keterampilan mengajar yang memadai serta mampu memberikan inovasi pembelajaran berupa penggunaan media pembelajaran yang sesuai dengan materi pelajaran yang diajarkan. Karena pada hakikatnya kegiatan belajar mengajar adalah proses komunikasi antara pemberi pesan dan penerima pesan dalam menyampaikan informasi melalui bahasa yang dapat diserap dan dihayati orang lain (Arsyad, 2016, hlm. 19).

Penggunaan media pembelajaran dapat menciptakan suasana pembelajaran yang menarik, praktis dan dapat memberikan motivasi bagi peserta didik dalam menulis. Menulis merupakan salah satu bentuk ide atau gagasan berupa pengalaman seseorang yang di jadikan sebagai hal luar biasa yang dituangkan dalam sebuah tulisan berupa teks cerita pendek yang disajikan dengan jelas dan dapat menarik minat pembaca (Mastini, 2016). Pada kegiatan observasi awal yang telah di lakukan kepada beberapa peserta didik, ditemukan bahwa kegiatan menulis masih dilakukan secara konvensional yakni peserta didik diminta untuk menulis cerpen di rumah sebagai pekerjaan rumah. Teknik dan langkah menulis cerpen hanya di jelaskan secara cepat di depan kelas. Yang diakhiri dengan tugas menulis cerpen di rumah, hasil yang diperoleh antara lain sebagian besar peserta didik tidak mengumpulkan tugas dengan berbagai alasan antara lain: lupa, sukar dikerjakan, tidak dapat mengembangkan ide, dan tidak cukup waktu. Kegiatan pembelajaran semacam ini dapat 
dikatakan tidak produktif karena pendidik hanya menyampaikan pengetahuan sebagai seperangkat fakta, yang harus dihafal secara terus menerus di kelas.

Menurut Umar Mansyur (2016, hlm. 330), menjelaskan bahwa ada manfaat dari pembelajaran cerpen di sekolah yakni untuk dapat mengembangkan las an an karakter saat ini dengan menanamkan salah satu sikap rasa terhadap tata nilai dalam kehidupan las a. SehinggaPendidik dituntut untuk berperan sebagai sumber utama dalam menerapkan sejumlah strategi untuk dapat mengaktifkan peserta didik pada proses pembelajaran menulis khususnya cerpen. Salah satu strategi tersebut adalah penggunan media pembelajaran kado ilmu yang dapat bermanfaat bagi peserta didik dalam menulis karangan berupa cerpen. Karena media ini berbentuk visual dan disediakan degan berbagai kata kunci untuk mempermudah peserta didik dalam merangkai kata dan kalimat yang akan menjadi sebuah cerpen (sulfemi, 2018).

Ada beberapa media pembelajaran yang sering digunakan adalah, replica, gambar, duplikat, planel, kertas koran, radio, video, dan masih banyak lainnya. Dalam penelitian ini, penulis menawarkan sebuah media pembelajaran dengan nama media Kado Ilmu. Media ini didalamnya terkandung berbagai macam kata kunci untuk dikembangkan menjadi sebuah teks cerita pendek. Peneliti merasa termotivasi ketika memperhatikan perilaku anak saat menerima dan membuka kado pesta ulangtahunnya. Dalam membuka kado, perilaku anak yang dicermati antara lain anak terlihat gembira menerima dan membuka isi kado, melihat apa saja yang terisi di dalamnya dan memilih yang mereka sukai.

Berdasarkan uraian di atas, penulis akhirnya mengambil media kado ilmu menjadi fokus pengkajian, dalam penelitian tindakan kelas dengan lokus peserta didik dengan judul "Penggunaan
Media Kado Ilmu dalam Meningkatkan Kemampuan Menulis Cerpen pada Peserta Didik. Judul ini menarik karena media merupakan media hasil inspirasi peneliti sendiri.Peneliti beranggapan bahwa media kado ilmudapat menimbulkan rasa ingin tahu dalam diri peserta didik, tentang apa yang ada di dalam kado. Tambahan pula peserta didik diberi kesempatan untuk memilih isi kado berupa berbagai kata kunci untuk mulai menuliskan kata- kata berikutnya hingga menjadi sebuah teks cerita pendek.

\section{METODE}

Jenis penelitian yang di lakukan yaitu penelitian tindakan kelas, dengan judul penggunaan media kado ilmu dalam meningkatkan kemampuan menulis cerpen pada peserta didik .Dengan subjek penelitian peserta didikkelas IX sebanyak 28 orang berjenis kelamin laki 11 orang, dan perempuan 17 orang. Waktu penelitian ini mulai dari tanggal 27 Januari sampai 27 Maret 2020. Adapun las an dalam pemilihan lokasi karena mudah dijangkau, ditemukan fenomena rendahnya kemampuan peserta didik dalam menulis cerita pendek, Serta dapat mempermudah peneliti dalam mencari data sesuai dengan judul yang sedang diteliti. Prosedur penelitian ini dilakukan dengan II siklus,yakni siklus I dan siklus II. Proses penelitian ini meliputi empat tahapan yakni: perencanaan, pelaksanaan, observasi, dan reflekas.

Adapun langkah-langkah yang digunakan di dalam kelas pada saat pembelajaran berlangsung dengan menggunakan media kado ilmu yakni: Pada siklus I pendidik menyampaikan $\mathrm{KD}$, IPK, dan tujuan pembelajaran serta ruang lingkup materi yang akan dipelajari dan menjelaskan skenario pembelajaran dalam pertemuan tersebut. Peserta didik dibentuk menjadi enam kelompok, setiap kelompok berdiskusi dan menuliskan ceritapendek dengan bantuan kata kunci 
yang tersedia di dalam media kadoilmu. Selanjutnyapendidikmenyuruhpesertadidi kmempresentasikan hasil pekerjaannya didepan kelas dan ditanggapi oleh kelompoklainnya. Pada penelitian ini peneliti bertindak sebagai pendidik, yang secara langsung mengamati aktivitas pembelajaran menulis Cerpen tersebut. Sehingga pada akhir pembelajaran dilakuan tes untuk mengetahui tingkat keberhasilan peserta didik disetiap siklus. Untuk lebih jelasnya dapat dilihat pada diagram alir dibawah ini.

Gambar 1. Diagam alir

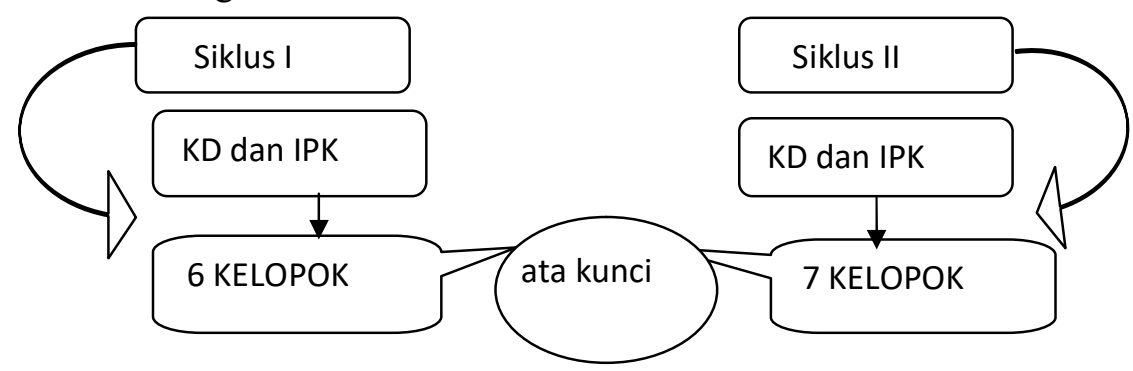

Tindak lanjut yang dimaksud adalah perbaikan atau upaya peningkatan setelah adanya catatan refleksi pada siklus I. Temuan pada siklus I ditindaklanjuti pada siklus II untuk mengurangi hal-hal yang kurang berhasil pada siklus I.Indikator keberhasilan pada pelaksanaan penelitian tindakan kelas ini dapat dilihat adanya peningkatan nilai aktivitas belajar peserta didik pada setiap siklusnya. Hasil belaja rpeserta didik dianggap tuntas apabila adanya peningkatan presentase pemerolehan nilai peserta didik setiap siklusnya, dan secara klasikal dianggap tuntas apabila mencapai $\geq 75 \%$ dari jumlah peserta didik seluruhnya mencapai nilai $\mathrm{KKM} \geq 70$. Teknik pengumpulan data merupakan salah satucara yang digunakan untuk mengumpulkan data. Denganmeggunakan metode observasi (pengamatan) peserta didik dan pendidik dan tes keterampilan menulis cerpen, sesuaidengan KKM yang telah ditentukan di sekolah tempat penelitaian berlangsung (Yusnita dan Munzir, 2017, hlm. 23- 38). teknik analisis data bertujuan untuk menjawab rumusan masalah. Teknik analisis data dilakukan dengan teknik deskriptif kualitatif melalui hasil tes dan non tes pada peserta didik dan pendidik.

\section{HASIL DAN PEMBAHASAN}

Pelaksanaan yang dilakukan pada penelitian tindakan kelas (PTK) dilaksanakan kedalam dua siklus, yaitu siklus I dan siklus II. Pembelajaran siklus 1 dilaksanakan pada tanggal 27Januari, 1Februari dan 3 Februari 2020. Pembelajaran siklus II dilakukan pada tanggal 8 Februari dan 10 Februari 2020. Kompetensi yang diajarkan adalah menulis cerita pendek dengan menggunakan strategi tiga kata kunci dengan media pembelajaran kado ilmu.

Pelaksanaan Siklus I merupakan pemberlakuan tindakan awal penelitian yang dilaksanakan pada tanggal 27 Januari 2020, dengan alokasi waktu 120 menit. Tindakan siklus I ini sebagai upaya untuk mengetahui keterampilan peserta didik dalam menulis cerpen. Adapun pelaksanaan pembelajaran menulis cerpen siklus I dengan tahapan sebagai berikut:

1. Pendidik menjelaskan mengenai KD dan Indikator serta materi yang akan dipelajari.

2. Pendidik menjelaskan bagaimana cara menggunakan media kado ilmu dalam menulis teks cerita pendek.

3. Peserta didik dibentuk 5 kelompok, yakni 4 kelompok beranggotakan 6 
orang sedangkan 1 kelompok beranggotakan 4 0rang.

4. Pendidik membagikan LKPD kepada peserta didik.

5. Setelah selesai menulis, pendidik menyuruh setiap anggonta membacakan tulisannyadan tanggapi oleh kelompok lainnya.

Data hasil tes menulis cerpen siklus I yang merupakan data awal setelah diberlakukannya tindakan pembelajaran dengan menggunakan media kado ilmu dengankriteria penilaiannya sebagai berikut: (1) isi cerpen sesuai dengan tema, (2) penggambaran watak tokoh, (3) struktur cerpen,(4) penggunaandiksi dangaya bahasa, dan (5) cara penyajian.Hasil tes setiap aspeknya dapat dilihat pada tabel sebagai berikut.

Gambar 2. Aspek penilaian siklus I

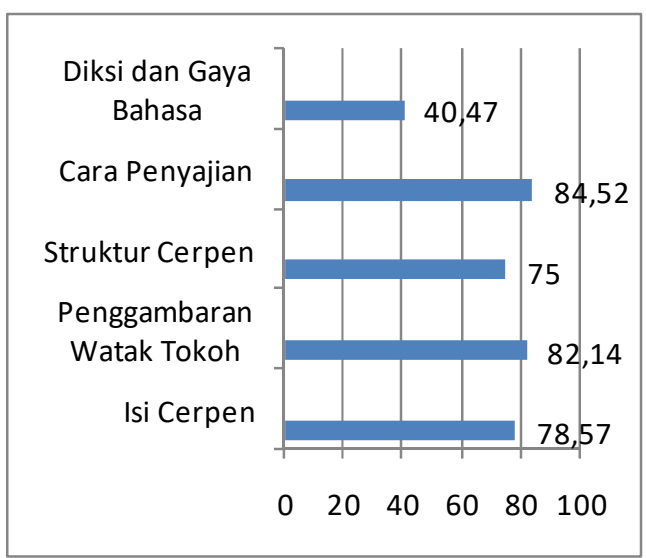

Berdasarkan gambar 3 dapat diketahui bahwa jumlah skor yang diperoleh peserta didik yang selalu konsistensebanyak $26,33 \%$, dan yang konsisten sebanyak 34,37\%, terdapat $14,00 \%$ yang kadang- kadang konsisiten. dan $26,00 \%$ yang tidak konsisten. Presentase ketuntasan diatas diperoleh dari skor pengamatan $\times$ jumlah peserta didik $\times$ aspek yang diamati.

Gambar 3. Aspek pengamatan peserta didik siklus I

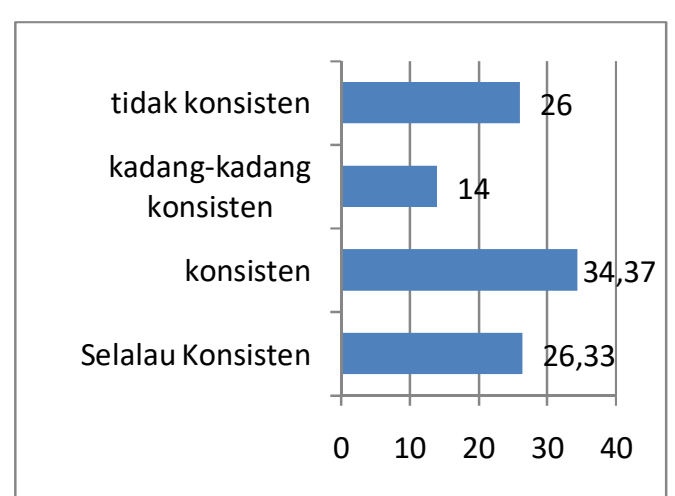

Gambar 4. Aspek pengamatan pendidik siklus I

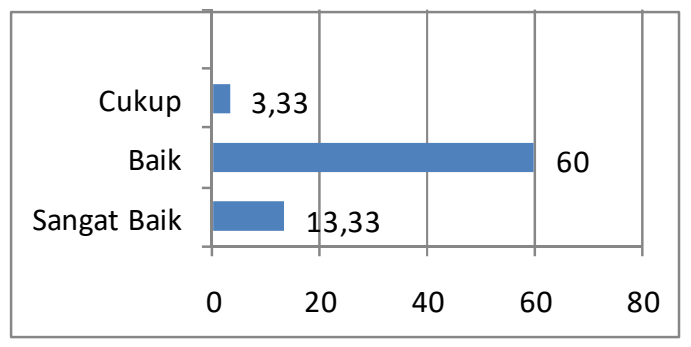

Berdasarkan gambar 4 dapat diketahui bahwa jumlah skor yang di peroleh pendidik sebanyak $8(13,33 \%)$ berkategori sangat baik, $36(60,00 \%)$ berkategori baik, dan sebanyak $2(3,33 \%)$ berkategori cukup, dengan jumlah total nilai 48 atau $80,00 \%$.

Refleksi Siklus 1

Selama pembelajaran berlangsung masih terdapat 20 peserta didik (71,43\%) yang terlihat kurang aktif dalam menjawab pertanyaan yang di berikan pendidik, dan belum berani membacakan cerpen di depan kelas. Selain itu, ada peserta didik yang kurang memperhatikan penjelasan dari pendidik, sehingga aktivitas pembelajaran menulis cerpen dalam kelas belum maksimal, sedangkan menurut refleksi peserta didik, mereka tidak mendapatakan giliran bersuten pada saat pembelajaran dengan media kado ilmu. Peserta didik yang bermain hanya ketua kelompok sedangkan anggotanya tetap di tempat duduk.

Tindak lanjut 
Hasil refleksi pada siklus I dijadikan sebagai perbaikan pada pembelajaran siklus II yaitu pendidik memperbanyak media kado ilmu sesuai dengan jumlah kelompok, sehingga semua peserta didik berperan aktif dalam bermain suten untuk mendapatkan kata kunci yang disediakan di dalam media kado ilmu tersebut. Usaha-usaha yang dilakukan pendidik diharapkan dapat meningkatkan prestasi ketuntasan Peserta didik dalam menulis cerpen selanjutnya.

Pelaksanaan pada Siklus II merupakan pemberlakuan tindakan kedua dalam penelitian yang dilaksanakan pada tanggal 8-10 februari 2020, dengan alokasi waktu 120 menit. Tindakan siklus II ini sebagai upaya untuk memperbaikikekuranganpeserta didik dalam menuliscerpen. Adapun pelaksanaan pembelajaran menulis cerpen siklus IIdengan tahapan sebagai berikut:

1. Pendidik menjelaskan mengenai KD dan indikator serta materi yang akan dipelajari.

2. Pendidik menjelaskan bagaimana cara menggunakan media kado ilmu dalam menulis teks cerita pendek.

3. Peserta didik dibentuk 7 kelompok, dengan jumlah anggota pada setiap kelompok 4 orang.

4. Pendidik membagikan LKPD kepada peserta didik.

5. Setelah selesai menulis, pendidik menyuruh setiap kelompok membacakan tulisannya dan tanggapi oleh kelompok lainnya.

Tindakan siklus II dilaksanakan karena pada siklus I keterampilan menulis cerpen peserta di dikkelas IX A SMP Negeri 1 Waigete, masih termasuk kategori kurang baik dan belum memenuhi batas ketuntasan belajar yang telah ditentukan. Sehingga pada siklus II dibuat rencana dan persiapan yang lebih matang dengan adanya perbaikanperbaikan dalam pembelajaran pada siklus II, maka hasil penelitian yang berupa nilai tes keterampilan menulis cerpen mengalami peningkatan dari kategori kurang menjadi kategori baik. Meningkatnya nilai tes ini diikuti pula dengan adanya perubahan perilaku Peserta didik, yaitu menjadi lebih aktif dan kreatif serta lebih antusias dalam mengikuti pembelajaran dengan menggunakan media kado ilmu. Dengan demikian, tindakan pada siklus II ini bertujuan untuk mengatasi masalah yang ada pada siklus I. Hasil selengkapnya pada siklus II mengenai tes dan non tes di uraikan secara rinci sebagai berikut.

Gambar 5. Aspek penilaian Siklus II

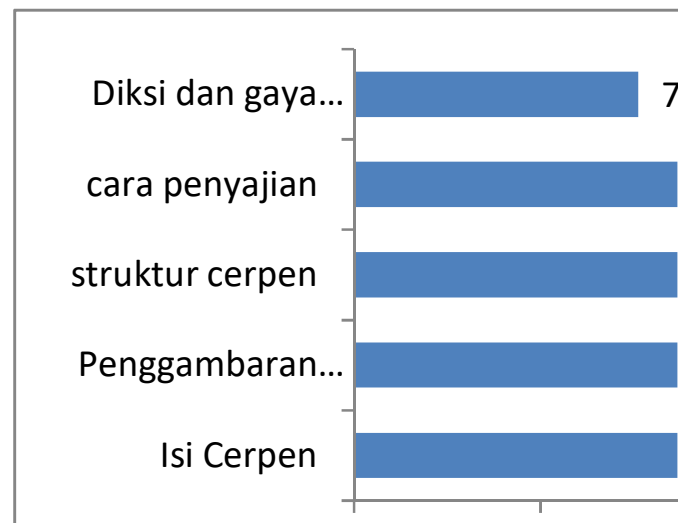

Gambar 6. Aspek pengamatan peserta didik siklus II

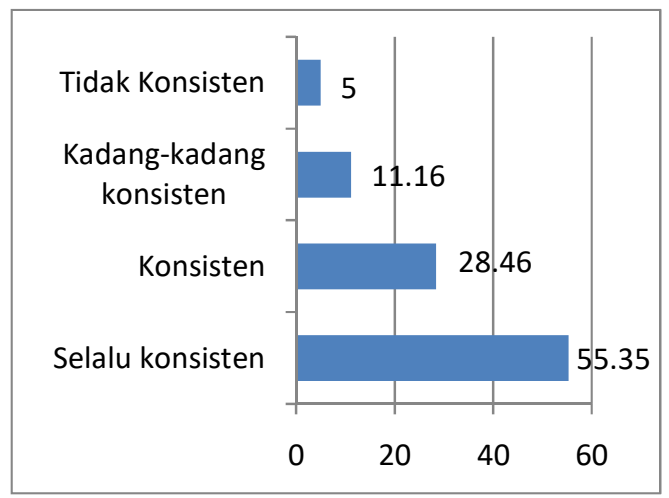

Gambar 7. Aspek pengamatan pendidik siklus II 


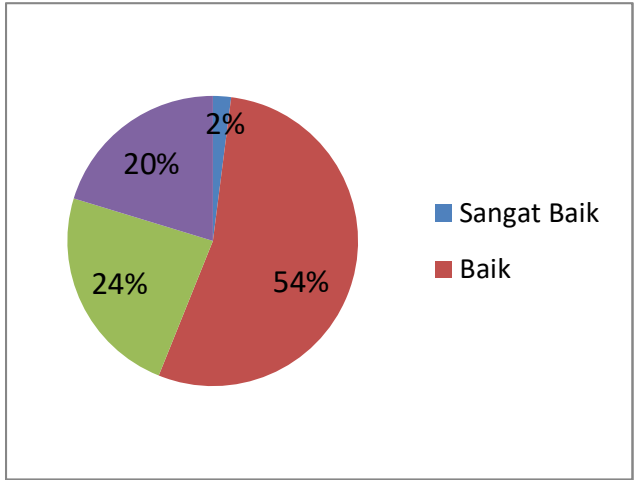

Berdasarkan gambar 5 tersebut dapat diketahui bahwa terdapat 27 peserta didik atau $96,42 \%$ yang tuntas sesuai KKM dan 1 peserta didik atau 4,00\% tidak tuntas. Aspek isi cerpen sesuai dengan tema mencapai 90,47\%, penggambaran watak $90,47 \%$, aspek struktur cerpen mencapai $94,04 \%$ dan aspek cara penyajian mencapai $98,80 \%$. Sementara itu, aspek penggunaan diksi dan gaya bahasa mencapai $76,19 \%$.

Berdasarkan gambar 6 dapat diketahui bahwa jumlah presentase yang selalu konsisten dan konsisten sebanyak $83 \%$ berkategori baik dengan skor yang di peroleh 55,35\% yang selalu konsisten dan $28,46 \%$ yang konsisten, sedangkan yang kadang- kadang konsisten dan tidak konsisten sebanyak $16,6 \%$ dengan skor yang di peroleh $11,16 \%$ yang kadangkadang konsisiten. $5,00 \%$ yang tidak konsisten.

jumlah skor yang di peroleh pendidik sebanyak 12 berkategori sangat baik, 36 berkategori baik, dengan jumlah total nilai 48 atau $80,00 \%$. Untuk lebih jelasnya disajikan pada gambar 7. Refleksi Siklus II Pembelajaran yang dilakukan pada siklus II ini merupakan tindakan perbaikan pada pembelajaran siklus I. Karenapresentase yang di perolehpeserta didik ini telah mencapai ketuntasan dengan kategori baik, sehingga penelitian ini berakhir pada siklus II.

Gambar 8. Perbedaan aspek penilaian siklus I dan siklus II

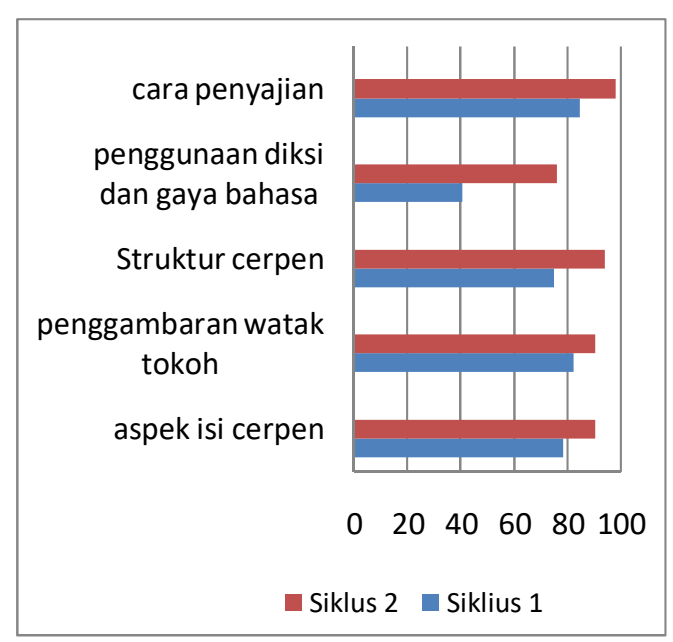

Dilihat dari gambar 8 maka dapat disimpulkan bahwa hasil pembelajaran pada siklus I dan II mengalami peningkatan hasil belajar pada peserta didik, yakni adanya perubahan dalam pemerolehan nilai pada peserta didik dari aspek 1) isi cerpen sesuai tema pada siklus I ketuntasan mencapai $78,57 \%$, siklus II mencapai $90,47 \%$, 2)pengambaran watak tokoh pada siklus I ketuntasan mencapai $82,14 \%$, siklus II mencapai $90,47 \%, 3$ ) struktur cerpen pada siklus I ketuntasan mencapai $75,00 \%$, siklusII mencapai $94,04 \%, 4)$ penggunaan diksi dan gaya bahasa pada siklus I ketuntasan mencapai $40,47 \%$, siklus II mencapai $76,19 \%$, 5) cara penyajian pada siklus I ketuntasan mencapai $84,52 \%$, siklus II mencapai $98,08 \%$.Dari hasil penelitian diatas maka penelitian ini dapat dikatakan berhasil dengan pemerolehan nilai ketuntasan yang di peroleh dari setiap aspek meningkat dari siklus 1 ke siklus II.

\section{KESIMPULAN}

Berdasarkan hasil penelitian tindakan kelas yang di laksanakan di SMP Negeri 1 Waigete dapat disimpulkan bahwa, dengan menggunakan media pembelajaran kado ilmu dapat meningkatkan kemampuan menulis 
teks cerita pendek pada peserta didik kelas IX A, dalam proses pembelajaran yang dapat dilihat dari perolehan nilai setiap peserta didik. Terbukti dengan adanya peningkatan kemampuan menulis cerpen pada aspek-aspek yang penting, dengan presentase ketuntasan dari aspek 1) isi cerpen sesuai tema pada siklus I ketuntasan mencapai $78,57 \%$, siklus II mencapai 90,47\%,2) pengambaran watak tokoh pada siklus I ketuntasan mencapai $82,14 \%$, siklus II mencapai $90,47 \%, 3$ ) struktur cerpen pada siklus I ketuntasan mencapai $75,00 \%$, siklus II mencapai $94,04 \%$, 4) penggunaan diksi dan gaya bahasa pada siklus I ketuntasan mencapai $40,47 \%$, siklus II mencapai $76,19 \%$, 5) cara penyajian pada siklus I ketuntasan mencapai $84,52 \%$, siklus II mencapai 98,08\%.

Proses pembelajaran menulis cerita pendek dengan menggunakan media kado ilmu, aktivitas peserta didik dan pendidik pun mengalami peningkatan dari siklus I ke siklus II sehingga penelitian dengan menggunakan media kado ilmu dapat dikatakan berhasil yang dapat dilihat dari perubahan perilaku peserta didik yang mengarah pada perilaku positif. Perilaku positif tersebut diantaranya, peserta didik merasa mampu menulis cerpen setelah pembelajaran berlangsung, peserta didik dapa belajar mandiri, dan lebih aktif dalam pembelajaran di kelas.

\section{DAFTAR PUSTAKA}

Ahsin, M. N. (2016). Peningkatan Keterampilan Menulis Karangan Narasi dengan Menggunakan Media Audiovisual dan Metode Quantum Learning. Refleksi Edukatika: Jurnal Ilmiah Kependidikan, 6(2).

Arsyad, A. (2011). Media Pembelajaran. Jakarta: PT. Raja Grafindo Persada.

Kette, E. S. S., Pratiwi, Y., \& Sunoto, S. (2016). Pengembangan Bahan Pelatihan Menulis Cerita Pendek Bermuatan Nilai Karakter untuk
Guru SMP Negeri Mata Pelajaran Bahasa Indonesia Se-Kota Kupang. Jurnal Pendidikan: Teori, Penelitian, dan Pengembangan, 1(4), 698-704.

Mansyur, U. (2018). Pemanfaatan Nilai kejujuran dalam Cerpen sebagai Bahan Ajar Berbasis Pendidikan Karakter. In Mengais Karakter dalam Sastra: HISKI Makassar, 330-339.

Mastini, S. S., Sumarwati.(2016). Peningkatan Keterampilan Menulis Cerpen Melalui Metode Pembelajaran Berbasis Pengalaman dan Media Audio Visual Pada Sekolah Menengah Pertama. Jurnal S2 Pendidikan Bahasa Indonesia, 1(1).

Santoso, dkk. (2010'). Keterampilan Menulis materi pembelajaran bahasa Indonesia SD.. Universitas Terbuka, Jakarta.

Sehndi, Y. (2016). Mengenal 25 Teori Sastra. Ombak, Yogyakarta.

Sulfemi, W. B. (2018). Penggunaan Metode Demontrasi Dan Media Audio Visual Dalam Meningkatkan Hasil Belajar Peserta Didik Mata Pelajaran IPS. Pendas Mahakam: Jurnal Pendidikan Dasar, 3(2), 151158.

Suryadi, E., \& Milawasri, F. A. (2018). Hubungan Penguasaan Kosakata Dengan Kemampuan Menulis Cerpen Mahasiswafkip Universitas Tridinanti Program Studi Pendidikan Bahasa Dan Sastra Indonesia. Jurnal Bindo Sastra, 2(2), 232-239.

Ulfa, D. M., \& Soenarto, S. (2017). Pengaruh Penggunaan Media Video dan Gambar terhadap Keterampilan Menulis Kembali Isi Cerita Kelas V. Jurnal Prima Edukasia, 5(1), 2234.

Yusnita, Y., \& Munzir, M. (2017). Peningkatkan Hasil Belajar 
Fon : Jurnal Pendidikan Bahasa dan Sastra Indonesia

Diterbitkan Oleh :

Program Studi Pendidikan Bahasa dan Sastra Indonesia

FKIP Universitas Kuningan

Pelajaran IPS dengan Contextual Teaching Learning Melalui Media Gambar Siswa Sekolah Dasar.
Volume 17 Nomor 1 Tahun 2021

Halaman 25-33

Faktor Jurnal Ilmiah Kependidikan, 4(1), 23-38. 